\begin{tabular}{|c|c|}
\hline 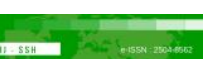 & Malaysian Journal of Social Sciences and Humanities (MJSSH) \\
\hline Malaysian Journal of & Volume 6, Issue 7, July 2021 \\
\hline (MJ - SSH) & e-ISSN : 2504-8562 \\
\hline & $\begin{array}{l}\text { Journal home page: } \\
\text { www.msocialsciences.com }\end{array}$ \\
\hline
\end{tabular}

\title{
Hubungan antara Tahap Konsep Kendiri Akademik dan Tahap Penghargaan Kendiri dalam kalangan Pelajar-Atlet di UKM Bangi
}

\author{
Nor Fatin Aqilah Mohammed Shohaimy ${ }^{1}$, Faridah Mydin Kutty ${ }^{1}$ \\ 1Fakulti Pendidikan, Universiti Kebangsaan Malaysia (UKM)
}

Correspondence: Nor Fatin Aqilah Mohammed Shohaimy (p101136@siswa.ukm.edu.my)

\begin{abstract}
Abstrak
Pelajar-atlet yang mempunyai konsep kendiri yang baik dan positif adalah salah satu aset kepada negara bagi membantu melahirkan ramai golongan pelajar yang berkualiti. Tujuan kajian ini dijalankan bagi mengkaji tahap konsep kendiri akademik dan tahap penghargaan kendiri serta mengkaji perhubungannya antara pelajar-atlet lelaki dan perempuan. Kajian ini berbentuk kuantitatif dengan kaedah tinjauan. Seramai 146 orang pelajar-atlet di UKM Bangi yang terlibat dalam kajian ini. Soal selidik Academic Self-Concept dan Rosenberg Self-Esteem Scale yang diedarkan dalam talian untuk mengumpul data. Data kuantitatif kemudiannya dianalisis secara deskriptif, ujian-t satu sampel dan korelasi pearson yang dianalisis menggunakan perisian SPSS. Dapatan kajian menunjukkan tahap konsep kendiri akademik berada pada tahap yang sederhana dengan min skor 2.96 manakala tahap penghargaan kendiri juga berada pada tahap yang sederhana iaitu min skor 2.89. Seterusnya perbezaan jantina pelajar-atlet perempuan mencatatkan konsep kendiri akademik yang tinggi iaitu min skor 2.97 daripada pelajar-atlet lelaki min skor 2.95 manakala pelajar-atlet lelaki mempunyai penghargaan kendiri yang tinggi iaitu min skor 2.92 berbanding pelajar-atlet perempuan min skor 2.84. Dapatan ini menjelaskan hubungan konsep kendiri akademik dan penghargaan kendiri adalah signifikan $(\mathrm{r}=0.728, \mathrm{p}<0.01)$. Hal ini dapat disimpulkan bahawa konsep kendiri akademik mempengaruhi penghargaan kendiri pelajar-atlet dan membuktikan bahawa pelajar-atlet perempuan tahu mengenai kemampuan mereka dalam bidang akademik manakala pelajar-atlet lelaki mempunyai perasaan yang positif dalam harga kendiri mereka. Implikasi kajian diharapkan dapat memberikan jurulatih, pensyarah, psikologis sukan dan pihak universiti untuk mengambil intervensi dan faktor-faktor yang mempengaruhi potensi pelajar-atlet.
\end{abstract}

Kata kunci: konsep kendiri akademik, penghargaan kendiri, pelajar-atlet

\section{Relationship between the Level of Academic Self-Concept and Self-Esteem among Students-Athletes At UKM Bangi}

\begin{abstract}
Student-athletes who have a good and positive self-concept is one of the assets to the country to help produce many quality students. This study examined the level of academic self-concept and the level of self-esteem as well as to examine the relationship between male and female student-athletes. The method in this study is quantitative using the survey method. A total of 146 student-athletes at UKM Bangi were involved. The Academic Self-Concept and Rosenberg Self-Esteem Scale questionnaires distributed online to collect data. Quantitative data were used to analyzed descriptively, t-test of one sample and
\end{abstract}


pearson correlation analyzed using SPSS software. The findings show that the level of academic selfconcept is moderate level with a mean score 2.96 while the level of self-esteem also is moderate level of mean score 2.89. Next, the gender differences female students recorded a high academic self-concept of mean score 2.97 from male students mean score 2.95 while male students had high self-esteem of mean score 2.92 compared to female students mean score 2.84 . These findings explain the relationship between academic self-concept and self-esteem is significant $(\mathrm{r}=0.728, \mathrm{p}<0.01)$. It can be concluded that the concept of academic self-influence affects students' self-esteem and proves that female students know about their abilities in the academic field while male students have a positive feeling in their self-esteem. The implications of the study are expected to provide coaches, lecturers, sports psychologists and the university to take the intervention and factors that influence the potential of students-athletes.

Keywords: academic self-concept, self-esteem, student-athlete

\section{Pengenalan}

Konsep kendiri merupakan penilaian oleh gabungan sendiri, penilaian yang dilakukan orang lain dan penilaian berkenaan persepsi orang lain terhadap diri mereka sendiri (Rogers, 1951). Konsep kendiri juga telah disusun dengan pelbagai hierarki dan tingkah laku individu secara peribadi serta kesimpulan mengenai diri (fizikal, sosial, akademik) dan mempunyai konsep kendiri global yang dikenali sebagai penghargaan kendiri (Marsh dan Martin, 2011). Menurut Berk (2009), konsep kendiri menjadi merudum apabila seseorang individu itu sudah meningkat ke alam remaja. Namun begitu, Berk menjelaskan lagi bahawa konsep kendiri juga kian menjadi realistik kerana interaksi dengan rakan-rakan sebaya, jalinan yang dibina oleh keluarga dan pengalaman yang diperoleh daripada persekolahan merupakan hasil untuk membandingkan pencapaian daripada bidang-bidang yang diceburi terutama sekali dalam pencapaian akademik dan pencapaian kokurikulum. Sehubungan dengan itu, kajian ini akan dikaitkan dengan konsep kendiri akademik kerana proses seseorang individu terhadap akademik, fizikal dan sosial merupakan aspek daripada konsep kendiri (Pintrich dan Schunk, 2002). Pelajar yang baik dan positif adalah satu aset kepada negara. Tambahan pula, pelajar yang mempunyai konsep kendiri yang tinggi akan melahirkan golongan pelajar yang berkualiti dari segi jasmani, emosi, rohani, intelek dan sahsiah sejajar dengan Falsafah Pendidikan Negara. Justeru, kajian ini memfokuskan kepada aspek konsep kendiri yang terbahagi kepada dua iaitu konsep kendiri akademik dan penghargaan kendiri.

\section{Sorotan Literatur}

Bidang Psikologi mempunyai istilahnya yang tersendiri, hal ini termasuk konsep kendiri yang ditakrifkan dengan pelbagai cara. Menurut Lindzey (1970), konsep kendiri secara umumnya disalurkan sebagai agen atau suatu proses dalam hal kendiri yang dimaksudkan sebagai sesuatu objek berkenaan dengan pengetahuan dan proses individu. Namun, terdapat juga ahli psikologi yang mentakrifkan konsep kendiri sebagai "melihat kendiri melalui cermin" yang bermaksud seseorang individu melihat dirinya melalui persepsi orang lain (Wylie, 1961). Dalam konteks ini, pelajar atau pelajar-atlet dapat mentafsir tentang diri mereka sendiri dengan mengikut panduan oleh pendapat dan persepsi oleh orang lain terhadap mereka. Penerangan ini menjelaskan tentang istilah konsep kendiri yang agak sukar untuk didefinisikan secara tepat dan jelas. Hal ini kerana, konsep kendiri dikaji oleh ahli-ahli psikologi daripada pelbagai perspektif dan pandangan yang berbeza. Walaubagaimanapun, Teori Carl Rogers (1961) menjadi sumber rujukan yang utama dalam kajian ini.

Carl Rogers (1961) yang merupakan pengasas kepada Teori Kendiri turut membincangkan mengenai konsep kendiri. Rogers (1961) menyatakan bahawa konsep kendiri adalah komponen yang penting dalam aspek perkembangan, pertumbuhan, personaliti dan penyesuaian dengan persekitaran. Rogers (1961) menjelaskan persepsi individu dan penilaian orang lain terhadap diri sendiri adalah gabungan daripada konsep kendiri dengan melihat bagaimana seseorang itu melihat dirinya dan berfikir bergantung kepada tahap kesedarannya tentang kekuatan dan kelemahan serta persepsi oleh orang lain. Sebagai contoh, jika 
seseorang individu menunjukkan tingkah laku yang tidak menyukai dirinya sendiri dan merasakan dirinya tidak baik, maka individu tersebut terdorong untuk melakukan apa yang dipersepsikan terhadap dirinya. Teori ini menganggap bahawa individu melakukan perkara yang meningkatkan konsep kendirinya adalah berdasarkan masalah-masalah dan pengalaman-pengalaman yang lalu. Hal ini menunjukkan bahawa kekuatan individu untuk membangunkan konsep kendiri bergantung kepada diri mereka sendiri. Oleh itu, individu perlu berhati-hati dalam melakukan apa sahaja dan menerima pendapat orang lain terutama sekali perkara yang boleh membawa unsur negatif.

\section{Rajah 1: Pembentukan Konsep Kendiri}

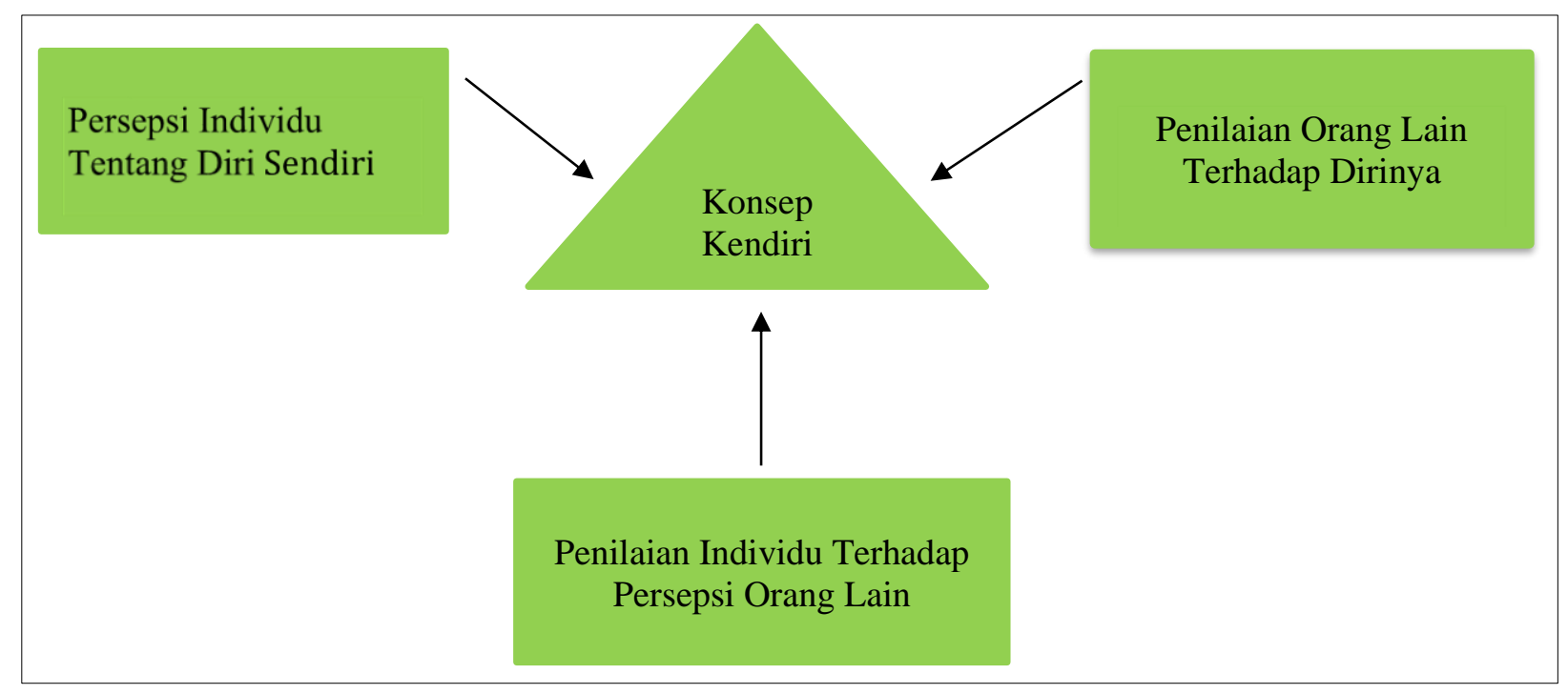

Sumber: Carl Rogers (1961)

\section{Konsep Kendiri}

Istilah diri, konsep kendiri dan identiti merupakan istilah yang saling berkaitan kerana ketiga-tiga istilah ini mengemukakan konsep mental yang diketengahkan dan dibentuk oleh persekitaran sosial dan merupakan panduan untuk melakukan sesuatu tindakan (Wehrle dan Fasbender, 2019).

Kajian oleh Anahita (2017) yang melakukan kajian mengenai perbandingan kemerosotan visual (VI) pada atlet dan bukan atlet wanita dari segi konsep kendiri dan harapan. Kaedah yang dilakukannya adalah dalam kajian kawalan kes, seramai 120 orang atlet buta dan buka atlet wanita yang meliputi 60 orang peserta dalam setiap kumpulan dipilih menggunakan kaedah persampelan rawak mudah. Kedua-dua kumpulan ini memberi tindak balas terhadap Roger's Self-Concept dan Synder's Hope Scales. Hasil daripada kajian ini menunjukkan bahawa terdapat perbezaan yang signifikan antara dua kumpulan VI daripada atlet dan bukan atlet dari segi konsep kendiri. Wanita atlet IV mempunyai konsep kendiri yang lebih baik dan harapan yang lebih tinggi berbanding dengan bukan atlet.

Vipende dan Emeribe (2014) mengkaji tahap konsep kendiri beberapa atlet dalam sukan yang terpilih di Nigeria. Kajian ini dilakukan dengan menggunakan soal selidik Index of Self-Esteem (ISE) untuk mengukur konsep kendiri. Seramai 97 orang sampel digunakan dalam kajian ini. Empat sukan yang terlibat meliputi sukan atletik, bola kerajang, tenis dan bola baling. Hasil kajian mendapati bahawa atlet lelaki dan wanita di dalam kajian ini mempunyai tahap konsep kendiri yang tinggi. Pemain tenis lelaki juga mempunyai konsep kendiri tertinggi. Oleh itu, kajian ini menyimpulkan bahawa atlet lelaki dan wanita yang dikaji mempunyai konsep kendiri yang tinggi dan ini mungkin menjadi sebab mengapa mereka menyertai sukan secara amnya.

Sikhwari (2014) menyatakan tujuan utamanya adalah untuk mengkaji hubungan antara motivasi, konsep kendiri dan pencapaian akademik. Di samping itu, pengkaji juga menyelidiki tentang perbezaan jantina. 
Pengkaji membina soal selidik sendiri dan digunakan untuk mengumpulkan data daripada sampel pelajar tahun dua yang dipilih secara rawak mewakili empat buah sekolah di universiti. Hasil daripada kajian tersebut, hubungan antara konsep kendiri, motivasi dan pencapaian akademik pelajar adalah signifikan. Maka, kajian ini dapat disimpulkan bahawa pentingnya konsep kendiri dan motivasi terhadap pencapaian akademik. Perhatian yang secukupnya kepada peningkatan konsep kendiri harus menawarkan intervensi agar dapat meningkatkan prestasi akademik pelajar.

\section{Konsep Kendiri Akademik}

Blegur, Wasak dan Pabala (2018) melaporkan kajian kualitatif mengenai strategi yang melatih perkembangan pelajar berkenaan konsep kendiri akademik semasa proses pembelajaran. Sampel yang dipilih merangkumi empat pelajar daripada semester enam mewakili program Pendidikan Jasmani, Kesihatan dan Rekreasi yang aktif melibatkan diri dalam sukan untuk berkongsi pengalaman pembelajaran mereka. Pengkaji secara tidak langsung menggunakan pemerhatian dengan cara wawancara yang mendalam, nota lapangan, perbincangan kumpulan dan teknik penyertaan. Hasilnya membuktikan bahawa konsep kendiri akademik pelajar-pelajar tersebut mempunyai keyakinan dalam konsep kendiri akademik yang dibentuk dan dilatih sekaligus membuktikan bahawa pelajar dengan konsep kendiri yang baik akan memperoleh keputusan akademik yang baik.

Penemuan dilakukan oleh Syahid, Jabeen dan Ansari (2016) yang mengkaji tentang hubungan keberkesanan diri, penghargaan kendiri dan konsep kendiri akademik dengan pencapaian akademik antara pelajar sarjana muda di universiti Pakistan. Penyusun utama yang mempengaruhi pencapaian ini adalah berdasarkan jantina. Hal ini adalah berkaitan dengan konsep kendiri akademik yang ditakrifkan sebagai persepsis terhadap kebolehan, pengetahuan dan kefahaman dalam persekitaran akademik. Sampel kajian yang terdiri daripada 200 orang siswazah daripada universiti terkenal di Pakistan menjawab soal selidik Academic Self-Concept Scale. Hasil kajian mendedahkan bahawa pelajar sarjana muda mempunyai konsep kendiri akademik yang sederhana sehingga tinggi tanpa perbezaan jantina yang signifikan.

Hansen dan Handerson (2019) menyelidik bahawa jurang pencapaian GCSE telah lama menjadi perhatian para akademik, pengulas sosial dan sebahagian besarnya untuk menetapkan anak-anak pada kejayaan akademik dan kerjaya mereka pada masa hadapan. Menurutnya lagi, kajian ini mengkaji tentang peranan kepercayaan pelajar terhadap kemampuan akademik mereka sendiri. Seterusnya, pengkaji membandingkan sama ada pelajar dengan konsep kendiri akademik yang tinggi mempunyai prestasi yang lebih baik atau lebih buruk dalam GCSE berbanding dengan pelajar yang mempunyai konsep kendiri akademik yang rendah. Hasilnya mendapati bahawa pencapaian tinggi dan rendah mempunyai kebarangkalian yang lebih tinggi untuk skor mata GCSE jika pelajar yang mempunyai konsep kendiri akademik yang tinggi daripada pelajar yang sama konsep kendiri akademik yang lebih rendah. Hal ini juga mendapati penemuan bahawa jika pihak lain memberi tumpuan untuk meningkatkan konsep kendiri akademik pelajar, maka mereka mungkin akan dapat meningkatkan prestasi mereka untuk GCSE.

Jaiswal dan Chouduri (2017) pula menyatakan perkara yang sama di mana konsep kendiri pelajar memainkan peranan yang penting mengenai kemampuan akademik mereka. Kajian yang dilakukan adalah bertujuan untuk mengkaji hubungan antara konsep kendiri akademik dengan pencapaian akademik pelajar sekolah menengah dan membandingkan konsep kendiri akademik pelajar menengah lelaki dan wanita. Sampel kajian seramai 615 orang pelajar sekolah menengah daripada kedua-dua jantina yang berumur lingkungan 14 hingga 17 tahun dan diambil daripada 15 buah sekolah menengah. Pengkaji mengukur pencapaian akademik dengan Purata Nilai Gred Kumulatif (PNGK) yang dilaporkan pada tahun yang sebelumnya. Soal selidik untuk mengukur konsep kendiri akademik adalah dengan menggunakan Academic Self-Concept Questionnaire. Hasil kajian ini menunjukkan bahawa terdapat hubungan yang positif antara konsep kendiri akademik dengan pencapaian akademik dan hubungannya lebih kuat bagi pelajar perempuan daripada pelajar lelaki. Selain itu, perbezaan jantina dalam konsep kendiri akademik dilaporkan bahawa pelajar perempuan mempunyai konsep kendiri akademik yang lebih tinggi daripada pelajar lelaki. 


\section{Penghargaan Kendiri}

Individu yang mempunyai harga diri yang tinggi mencari maklum balas yang mengesahkan konsep kendiri positif mereka, daripada yang lain yang penting, yang menjadikan konsep kendiri mereka lebih stabil dan lebih jelas (Kawamoto, 2020). Walaupun beberapa kajian telah menunjukkan tidak ada perbezaan dalam penghargaan kendiri antara atlet individu dan pasukan (Akelaitis \& Malinauskas, 2018) tetapi tahap penghargaan kendiri yang lebih tinggi adalah penting sebagai strategi mengatasi pengurusan tekanan dalam sukan (Káplanová, 2018). Kajian menunjukkan bahawa penghargaan kendiri yang tinggi mempunyai kesihatan fizikal dan mental yang lebih baik dan berjaya mengembangkan penghargaan kendiri terhadap tekanan, lebih yakin dan tidak lari daripada sebarang masalah atau konflik, bersedia demi diri sendiri serta bersedia menerima kritikan (Bojanic et al., 2019).

Muhammad Arshad, Syed Muhammad dan Khalid (2015), mengkaji mengenai penilaian harga kendiri dan prestasi akademik dalam kalangan pelajar universiti setelah beberapa isu berkaitan tingkah laku dan pendidikan timbul. Seramai 80 orang pelajar yang terlibat sebagai sampel melalui pemilihan dengan menggunakan soal selidik Rosenberg Self-Esteem Scale dan Academic Performance Rating Scale bagi mengukur penghargaan kendiri dan prestasi akademik mereka. Pengkaji mendapati bahawa terdapat hubungan yang signifikan antara penghargaan kendiri dan prestasi akademik lebih-lebih lagi dalam kalangan pelajar perempuan yang mempunyai skor tinggi dalam prestasi akademik berbanding dengan pelajar lelaki yang mempunyai skor tinggi dalam penghargaan kendiri. Hasil daripada keputusan ini mendapati bahawa penghargaan kendiri yang tinggi membawa kepada prestasi akademik yang baik.

Ali Hassan, Muhammad Aqeel dan Humaira (2016) mempunyai dapatan yang berbeza apabila mengkaji berkenaan dengan peranan ponteng dalam konsep kendiri akademik, penghargaan kendiri dan pencapaian akademik yang dibuat melalui perbandingan antara pelajar yang ponteng dan pelajar yang menepati masa. Sampel seramai 200 orang pelajar mengambil bahagian dalam kajian ini. Soal selidik Academic Self Concept versi Urdu dan Self-Esteem Scales digunakan. Hasil kajian menunjukkan pelajar yang menepati masa memperoleh pencapaian akademik yang cemerlang berbanding pelajar yang ponteng sekolah. Kajian ini juga menunjukkan hubungan yang signifikan antara penghargaan kendiri dan konsep kendiri akademik tanpa mengira ponteng atau menepati masa. Namun begitu, pelajar yang menepati masa mempunyai pencapaian akademik yang lebih baik daripada pelajar yang ponteng tetapi tidak ada kaitan dengan penghargaan kendiri dan konsep kendiri akademik. Hal ini tidak berperanan sebagai penghargaan kendiri dalam meramal konsep kendiri akademik.

Selain itu, kajian yang dilakukan oleh Galante dan Ward (2017) mengkaji perbezaan penghargaan kendiri antara atlet wanita Divisyen I NCAA dan bukan atlet. Kajian ini adalah mengenai penghargaan kendiri dan sifat kepimpinan transformasional. Peserta yang terdiri daripada 635 wanita yang menyelesaikan tinjauan secara atas talian dengan menggunakan Students Leadership Practises Inventory dan Rosenberg's Self-Esteem Scale. Laporan daripada kajian yang dilakukan menunjukkan atlet wanita lebih cenderung terhadap penghargaan kendiri dan memiliki ciri-ciri kepimpinan yang tinggi berbanding bukan atlet.

Seyedeh, Zahra dan Mohadeseh (2013) mengkaji tentang perbandingan dan menentukan hubungan antara penghargaan kendiri dan konsep kendiri pelajar-atlet dan bukan pelajar-atlet atlet wanita dan lelaki di Universiti Azad Islam Cawangan Sari. Seramai 200 orang pelajar yang terdiri daripada 100 orang pelajar-atlet dan 100 orang bukan pelajar-atlet dipilih secara rawak dan diuji dengan soal selidik Eysenck Self-Esteem dan Roger's Self-Concept. Hasil daripada kajian ini melaporkan bahawa tidak ada hubungan yang signifikan antara penghargaan kendiri pelajar-atlet dan bukan pelajar-atlet. Walau bagaimanapun, terdapat hubungan yang signifikan antara penghargaan kendiri pelajar bukan-atlet wanita dan bukan pelajar-atlet lelaki. Oleh itu, aktiviti sukan adalah antara faktor yang dapat memberi tanggapan tentang apa yang dirasakan oleh individu itu sendiri.

Mathew, Pious dan Sheela (2017) melakukan kajian dalam membandingkan penghargaan kendiri dalam kalangan remaja atlet dan bukan atlet. Dapatan kajiannya menunjukkan bahawa atlet mempunyai penghargaan kendiri yang jauh lebih tinggi berbanding dengan bukan atlet sekali gus mendapati atlet yang kompetitif juga mempunyai penghargaan kendiri yang lebih tinggi daripada atlet rekreasi. 
Menurutnya, penyertaan sukan telah menunjukkan bukti untuk mempengaruhi penghargaan kendiri remaja. Kajian ini diterokai dengan mengukur kesan pada sampel remaja, jantina, penyertaan dan tahap penyertaan. Sampel yang terlibat dalam kajian ini meliputi seramai 187 remaja yang mewakili 89 orang bukan atlet dan 98 atlet antara gred lima hingga lapan. Seterusnya atlet dibahagikan kepada dua kumpulan iaitu seramai 50 atlet rekreasi dan 48 atlet yang kompetitif. Sampel ini dikumpul melalui persampelan bukan rawak. Soal selidik yang digunakan adalah Rosenberg Self-Esteem Scale bagi mengukur penghargaan kendiri peserta tersebut.

\section{Metod Kajian}

Reka bentuk kajian ini merupakan kajian yang berbentuk bukan eksperimental iaitu dengan menggunakan kajian korelasi. Menurut Ketner, Smith dan Parnell (1997), kajian korelasi digunakan apabila untuk mencari hubungan dua atau lebih pembolehubah sama ada mempengaruhi antara satu sama lain ataupun tidak. Sehubungan dengan itu, pengumpulan data dilakukan dengan menggunakan pendekatan kaedah kuantitatif. Kaedah kuantitatif adalah mengumpul data melalui instrumen soal selidik yang diberi oleh pengkaji. Pengkaji menggunakan kajian korelasi supaya dapat memberi dan memperoleh maklumat yang jelas dan tepat serta memenuhi kehendak persoalan kajian yang dilakukan.

Perlaksanaan populasi dan sampel kajian ini melibatkan pelajar-atlet di Fakulti Pendidikan UKM Bangi yang melibatkan diri dalam apa jua pertandingan sukan mewakili universiti. Seramai 146 orang pelajaratlet lelaki dan perempuan yang mewakili universiti dalam bidang sukan dijadikan sebagai sampel di dalam kajian ini. Selanjutnya, sampel kajian ini merupakan pelajar yang terdiri daripada pelajar ijazah sarjana muda yang berumur lingkungan 20 tahun ke atas.

Soal selidik Academic Self-Concept Questionnaire (ASCQ) oleh Liu, Wang dan Perkins (2005) digunakan untuk mengenal pasti konsep kendiri akademik pelajar-atlet UKM Bangi. Soal selidik ini mencerminkan konsep-konsep yang terdiri daripada konsep kendiri akademik kerana model hierarkinya terdiri daripada satu faktor. ASCQ mempunyai 19 item dan melibatkan dua faktor yang utama iaitu tentang keyakinan akademik dan usaha akademik. Keyakinan akademik adalah penilaian yang dilakukan tentang perasaan dan persepsi pelajar-atlet mengenai kecekapan mereka dalam bidang akademik sementara usaha akademik pula adalah untuk menyelidik komitmen dan penglibatan pelajar-atlet serta minat mereka terhadap tugasan universiti. Menurut Dhingra (2013), soal selidik Rosenberg Self-Esteem Scale oleh Rosenberg (1965) merupakan skala ukuran yang banyak digunakan untuk mengukur harga diri sebagai konstruk satu dimensi. Soal selidik ini terdiri daripada 10 item yang mengukur nilai diri dengan mengambil kira perasaan positif dan negatif mengenai diri sendiri. Menurut Shevlin, Bunting dan Lewis (1995), banyak kajian yang menyokong model satu dimensi ini. Sebilangan besar pengkaji memberi pendapat bahawa RSES lebih tepat untuk dikonseptualisasikan sebagai penyelesaian yang mempunyai dua faktor seperti harga diri yang positif dan negatif (Owens, 1994). Oleh itu, dua set soal selidik ini meliputi 29 item yang dikemukakan kepada responden untuk dijawab. Item-item dalam soal selidik ini dibahagikan kepada tiga bahagian iaitu bahagian demografi, bahagian konsep kendiri akademik dan penghargaan kendiri. Item-item ini dilengkapkan dengan menggunakan format skala Likert 4 titik yang bermula daripada sangat setuju hingga sangat tidak bersetuju. Item yang mempunyai jumlah skor tertinggi menunjukkan konsep kendiri akademik dan penghargaan diri lebih tinggi.

Pengkaji terlebih dahulu menjalankan kajian rintis sebelum melaksanakan kajian yang sebenar. Tujuan kajian rintis dilakukan adalah untuk membantu pengkaji mengenal pasti tahap kemunasabahan dan perlaksanaan dalam kajian yang sebenar di samping meningkatkan kesahan dalam instrumen tersebut. Pengkaji menjalankan ujian rintis secara atas talian dengan mengedarkan soal selidik melalui Google Form. Pengkaji menggunakan subjek yang lain di mana subjek tersebut mempunyai ciri-ciri yang sama dengan subjek populasi yang dipilih dalam kajian. Subjek untuk kajian rintis ini melibatkan seramai 30 orang pelajar daripada Fakulti Sains Sukan dan Rekreasi UiTM Perlis iaitu pelajar sains sukan dan pelajar pengurusan sukan. Keputusan daripada kajian rintis tersebut menunjukkan nilai pekali alfa bagi konsep kendiri akademik sebanyak 0.875 dan nilai pekali alfa bagi penghargaan kendiri sebanyak 0.747 . 
Data-data yang dikumpulkan dengan menggunakan kedua-dua instrumen iaitu ASCQ dan RSES dianalisis menggunakan SPSS Windows Versi 15. Data yang diperoleh untuk menganalisis digunakan sebagai statistik deskriptif. Umumnya, demografi responden yang terlibat dalam kajian ini menerangkan tentang kekerapan dan peratusan dengan menggunakan statistik deskriptif. Di samping itu, ujian T satu sampel digunakan untuk mengkaji perbezaan antara pelajar-atlet lelaki dan perempuan. Seterusnya, statistik inferensi yang sesuai digunakan bagi menguji hipotesis kajian tentang hubungan konsep kendiri akademik dan penghargaan kendiri pelajar-atlet.

\section{Hasil Kajian}

\section{Demografi Responden}

Jadual 1 menunjukkan data demografi responden berkaitan jantina, umur dan tahap pengajian berdasarkan bilangan dan peratusan responden.

Jadual 1: Demografi Responden (N=146)

\begin{tabular}{llll}
\hline Maklumat Demografi & Bilangan & Peratus (\%) \\
\hline Jantina & Lelaki & 87 & 59.6 \\
& Perempuan & 59 & 40.4 \\
Umur & 20 tahun - 21 tahun & 59 & 40.4 \\
& 22 tahun - 23 tahun & 70 & 47.9 \\
& 24 tahun ke atas & 17 & 11.6 \\
Tahap & Ijazah Sarjana Muda & 144 & 98.6 \\
Pengajian & Ijazah Sarjana & 2 & 1.4 \\
\hline
\end{tabular}

\section{Tahap Konsep Kendiri Akademik}

Jadual 2 menunjukkan keputusan analisis deskriptif bagi nilai min secara keseluruhan untuk tahap konsep kendiri akademik $(\mathrm{M}=2.96, \mathrm{SP}=0.476)$. Hal ini disimpulkan bahawa tahap konsep kendiri akademik dalam kalangan pelajar-atlet UKM Bangi adalah berada pada tahap yang sederhana.

Jadual 2: Nilai min bagi Item Konsep Kendiri Akademik

\begin{tabular}{lccc}
\hline \multicolumn{1}{c}{ Item } & Bilangan Item & Nilai Min & Sisihan Piawai \\
\hline $\begin{array}{l}\text { Konsep Kendiri } \\
\text { Akademik }\end{array}$ & 19 & 2.96 & 0.476 \\
\hline
\end{tabular}

\section{Tahap Penghargaan Kendiri}

Jadual 3 menunjukkan keputusan analisis deskriptif bagi nilai min secara keseluruhan untuk tahap penghargaan kendiri $(\mathrm{M}=2.89, \mathrm{SP}=0.511)$. Hal ini disimpulkan bahawa tahap penghargaan kendiri dalam kalangan pelajar-atlet UKM Bangi adalah berada pada tahap yang sederhana

Jadual 3: Nilai min bagi Item Penghargaan Kendiri

\begin{tabular}{cccc}
\hline Item & Bilangan Item & Nilai Min & Sisihan Piawai \\
\hline Penghargaan Kendiri & 10 & 2.89 & 0.511 \\
\hline
\end{tabular}




\section{Perbezaan Konsep Kendiri Akademik Dan Penghargaan Kendiri Berdasarkan Jantina}

Jadual 4 menunjukkan hasil ujian-t bagi menguji kedua-dua perbezaan antara konsep kendiri akademik dan penghargaan kendiri pelajar-atlet lelaki dan perempuan UKM Bangi. Hasil daripada analisa ujian- $t$ didapati bahawa tidak terdapat perbezaan yang signifikan konsep kendiri akademik $[t=-0.262, p=$ 0.794] dan penghargaan kendiri $[t=0.955, p=0.341]$ antara pelajar-atlet lelaki dan perempuan UKM Bangi. Dapatan ini juga menunjukkan pelajar-atlet perempuan mempunyai konsep kendiri akademik yang tinggi $(M=2.97)$ berbanding pelajar-atlet lelaki $(M=2.95)$. Walaubagaimanapun, dapatan bagi penghargaan kendiri adalah lebih tinggi $(\mathrm{M}=2.92)$ berbanding pelajar-atlet perempuan $(\mathrm{M}=2.84)$.

Jadual 4: Ujian-t Perbezaan Konsep Kendiri Akademik Dan Penghargaan Kendiri Berdasarkan Jantina

\begin{tabular}{llllcc}
\hline \multicolumn{1}{c}{ Item } & Jantina & N & Nilai Min & Nilai t & Sig.P \\
\hline Konsep Kendiri & Lelaki & 87 & 2.95 & -.262 & .794 \\
Akademik & Perempuan & 59 & 2.97 & & \\
Penghargaan & Lelaki & 87 & 2.92 & .955 & .341 \\
Kendiri & Perempuan & 59 & 2.84 & & \\
\hline
\end{tabular}

\section{Hubungan Antara Tahap Konsep Kendiri Akademik Dengan Tahap Penghargaan Kendiri}

Jadual 5 menunjukkan keputusan pengujian hipotesis kesan langsung menghasilkan satu dapatan penting, iaitu tahap konsep kendiri akademik $(r=0.728, p<0.01)$ mempunyai hubungan yang signifikan dengan tahap penghargaan kendiri dalam kalangan pelajar-atlet UKM Bangi. Hal ini dapat disimpulkan bahawa tidak terdapat hubungan yang signifikan antara tahap konsep kendiri akademik dengan tahap penghargaan kendiri dalam kalangan pelajar-atlet UKM Bangi.

Jadual 5: Hubungan Antara Tahap Konsep Kendiri Akademik Dengan Tahap Penghargaan Kendiri

\begin{tabular}{lcc}
\hline & \multicolumn{2}{c}{ Tahap penghargaan kendiri } \\
\cline { 2 - 3 } Tahap konsep kendiri akademik & $\mathbf{r}$ & Sig. P \\
\hline$* * \mathrm{p}<0.01$ & $0.728^{* *}$ & .000 \\
\hline
\end{tabular}

\section{Kesimpulan}

Secara kesimpulannya, hasil dapatan kajian telah menunjukkan tentang perhubungan antara konsep kendiri akademik dan penghargaan kendiri dalam kalangan pelajar-atlet di UKM Bangi berada pada tahap yang sederhana yang membawa maksud konsep kendiri akademik secara tidak langsung mempengaruhi harga kendiri seseorang. Seperti yang ditunjukkan dalam kajian ini, pelajar-atlet perempuan mempunyai tahap konsep kendiri akademik yang tinggi berbanding lelaki. Hal ini membuktikan bahawa pelajar-atlet perempuan tahu mengenai kemampuan mereka dalam bidang akademik yang melibatkan keyakinan akademik dan usaha akademik. Seterusnya, pelajar-atlet lelaki pula mempunyai penghargaan kendiri yang tinggi berbanding pelajar-atlet perempuan. Hal ini kerana, pelajar lelaki mempunyai perasaan yang positif terhadap harga diri mereka. Hal ini dapat dinyatakan bahawa kedua-dua elemen konsep kendiri akademik dan penghargaan kendiri ini merupakan aspek yang penting terutama sekali kepada pelajar-atlet untuk meningkatkan bidang akademik dan bidang sukan mereka. Cadangan kajian lanjutan diharapkan supaya konsep kendiri akademik dan penghargaan kendiri boleh dilanjutkan dengan melakukan kajian kepada universiti-universiti dalam konteks Malaysia sama ada di IPTA atau IPTS. Hal ini juga boleh dilakukan dengan mengambil kira pelbagai bidang sukan yang mereka ceburi sama ada dalam kategori sukan berkumpulan atau individu dengan melibatkan lebih ramai responden. Kajian lanjutan boleh dijalankan dalam bentuk kualitatif bagi mengambil kira konsep kendiri 
akademik dan penghargaan kendiri dengan lebih terperinci melalui temu bual dan soalan-soalan yang dikemukakan.

\section{Rujukan}

Abdul Rahim, M. M. \& Siti Norlia, M. (2017). Relationship between Academic Self-Concept and Academic Achievement Among UiTM Centre of Football Athletes. International Journal of Management and Applies Science, 3(2), 71-77.

Aghdasi MT, Ahmad A, editors. Comparing Anxiety and Self-concept Rate of Athletic and non-athletic Students of Orumiye University. First International Scientific Sports Conference of Universities of Islamic World; 2008; Islamic Azad University-Sport Research Center, Tehran Islamic Azad University [Proceeding in Farsi].

Ahmad, I., \& Rana, S. (2012). Affectivity, achievement motivation, and academic performance in college students. Pakistan Journal of Psychological Research, 27(1), 107-120.

Ahmed, D., Mladenovic, M., King Yan Ho, W., Ki-Cheon, L. \& Ali Khan, B. (2014). Exploring the perception of self esteem among high school athletes. Sport Logia, 10(2), $81-88$.

Akelaitis A, V. \& Malinauskas, R. (2018). The expression of emotional skills among individual athletes. Pedagogics Psychology.

Anahita, K. K. (2017). Sport as an effective goal to increase self-concept and hope: a comparison study between athlete and non-athlete women with visual impairments. Self-concept and hope in visually impaired women, 3(2), 98-103.

Arshad, M., Haider Zaidi, S. M. I. \& Mahmood, K. (2015). Self-Esteem \& Academic Performance Among University Students. Journal of Education And Practise, 6(1), 156-162.

Asady, S. K., Tasaddhogi, Z. \& Tavakoli, M. (2013). Comparing self-esteem and self-concept of athletic and non-athletic students and finding a relationship between these two variables. Annals Ofapplied Sport Science, 1(1), 28 - 33.

Bendíková E. (2016). Changes in the posture of students due to equipment-aided exercise programs that are applied in physical and sport education. Journal Of Physical Education And Sport, 16(2), 281-286.

Blegur, J., Mae, R. M., \& Wasak, M. R. P. (2018). Konsep diri akademik sebagai solusi mengendalikan kecemasan berkomunikasi peserta didik. Indigenous: Jurnal Ilmiah Psikologi, $3(1), 47-59$.

Bojanić, Z., Nedeljković, J., Šakan, D., Mitić. P., Milovanović. I. \& Drid, P. (2019). Personality traits and self-esteem in combat and team sports. Frontiers in Psychology,Movement Science and Sport Psychology.

Cohn, P. (2006). Self-esteem in the athlete. Brian Mackenzie's Successful Coaching.

Galante, M. \& Ward, R.M. (2017). Female student leaders: An examination of transformational leadership, athletics and self-esteem. Personality and individual differences, 106, 157-162. http://dx.doi.org/10.1016/j.paid.2016.11.017

Goulimaris, D., Mavridis, G., Genti, M. \& Rokka, S. (2014). Relationships between basic psychological needs and psychological well-being in recreational dance activities. Journal of Physical Education and Sport, 14(2), $277-284$.

Guay, F., Chanal, J., Ratelle, C. F., Marsh, H. W., Larose, S., \& Boivin, M. (2010). Intrinsic, identified, and controlled types of motivation for school subjects in young elementary school children. British Journal of Educational Psychology, 80(4), 711-735.

Salina, H., Faridah, H. \& Sarina, M. J. (2017). Academic self-concept among the pre-diploma students. International Academic Research Journal Of Social Science, 3(1), 138-134.

Hossain, Z. \& Shahare, A. (2019). A Comparative Study Of Self-Concept Of School Going Female Hockey Players Of Urban And Rural Area. Aayushi International Interdisciplinary Research Journal (AIIRJ), 6(12), 78-83.

Jaiswal, S. K. \& Choudhuri, R. (2017). Academic Self-Concept And Academic Achievement Of Secondary School Students. American Journal Of Educational Research, 5(10), 1108-1113.

Singh, J. \& Battan, K. K. (2019). Study on self-esteem among individual sports, team sports and esports. International Journal Of Physiology, Nutrition And Physical Education, 4(2), 
430-432.

Jalali J, Sardroodi. Investigating Sport Effects on Mental-Motional Skills as well as Social Adjustment of 8 to 9 Years Olds Young male Individuals in Tehran. Tehran: Tarbiat Modares University; 1998.

Kaba, A. M., \& Talek, Y. (2015). Self-Concept and Academic Success Among University Students. International Arts \& Sciences.

Kamble, V.S., Naik, B.A. (2013). Manual of academic self-concept scale. Prasad Psycho Corporation: New Delhi.

Káplanová, A. (2018). Self-esteem, anxiety and coping stress strategies to manage stress in ice hockey. Acta Gymn. 49, 10-15.

Kawamoto, T. (2020). The moderating role of attachment style on the relationship between self-concept clarity and self-esteem. Personality and individual differences. https:// doi.org/10.1016/j.paid.2019.109604.

Kayode, Kolawole. \& Comfort. (2016). Academic Motivation, Satisfaction and Resilience as Predictors of Secondary School Studentse Academic Confidence in Ogun State, Nigeria. IOSR Journal of Research and Method in Education, (IOSR-JRME), 6(6), 5964.

Kvintová, J. \& Sigmund, M. (2016). Physical activity, body composition and health assessment in current female University students with active and inactive lifestyles. Journal of Physical Education and Sport, 16 Supplement issue (1), $627-632$.

Liu, W. C. \& Wang, C. K. J. (2005). Academic self-concept: A cross-sectional study of grade and gender differences in a Singapore secondary school. Asia Pacific Education Review, 6(1):20-27.

Rogers, C. R., Client-centered Therapy. New York: Houghton Mifflin, 1951. 